\title{
INFLUENCE OF BACTERIAL IMMUNOMODULATORS ON THE INDUCTION OF SPECIFIC IGG WITH PATIENTS DURING A PERORAL HYPOSENSITIZATION THERAPY
}

\author{
Šárka Hradilová
}

Department of Immunology, Medical Faculty, Palacký University, 77515 Olomouc, Czech Republic

Recevied June 18, 2001

Key words: Immunomodulators / Bacterial adjuvans/ Peroral hyposenzibilization

Peroral administration of allergen during hyposensitization therapy with allergic patients is in comparison with an administration by injection of a wilder inductor of specific IgG antibodies. The peroral administration of bacterial immunomodulators increases IgG formation significantly. The described experiment examines the influence of bacterial immunomodulator Olimunostim on the level of specific antibodies during peroral hyposensitization therapy with allergic patients.

\section{INTRODUCTION}

Allergy is common worldwide. However, the tendency to certain allergic diseases is not the same in various age groups, sexes and races, and recently, an unusual growth of this diseases has been observed, especially in industrial agglomerations of the civilized world. This un-common growth is connected not only to environment pollution, but also to missing parasitism in childhood ${ }^{1}$. In communities where parasitic diseases are present, high levels of serum IgG are typical, owing to permanent stimulation of $\operatorname{IgE}$ production and, presumably, tissue fat cells are saturated by specific IgE antibodies against parasites. The mechanism of immune response mediated by relationship of IgE and fat cell is advantageous for a host under these circumstances. In communities where no parasitism is present, the immune response with IgE participation is only of peripheral importance for protective immunity. However, it has a capacity to react to otherwise harmless antigens from the external environment during an allergic reaction.

Treatment of sub allergic reaction by means of hyposensitization based on repeated allergen administration in increasing concentrations has been considered as a causal therapy. This therapy method developed from the assumption, verified by a number of experimental results ${ }^{2,3}$ based on the fact that the repeated allergen administration induces antibodies of an IgG class, especially $\mathrm{IgG}^{1}$ and $\mathrm{IgG}_{4}{ }^{4}$. Their therapeutic importance consists in the capacity to bind allergen determinants specifically and to act as a competitive inhibitor of immunoglobulin $\operatorname{IgE}^{5}$.

An allergen ${ }^{6}$ is any antigen, which produces an allergic response ${ }^{7}$. The term is used both for the antigen molecule, and for its source, i.e. pollen grains, animal hair, insect venom or foods. An allergic reaction is characterised mainly by the release of some significant mediators, such as histamine 8,9 and many others. The relationships however between structure and the immunogenic activity of allergen proteins are not entirely clear. Especially in the case of pollen allergens, a number of short amino acid sequences 10 was described, which present specific determinants for idiotypes of IgE antibodies in allergic reactions. Such sequences are designated as allergen motifs. They are relativelly conservative in the plant kingdom and they show a considerable stage of sequence homology in various taxons. This fact is often a cause of cross reactivity 11,12 .

A very frequent reaction is allergy to mites, insect venom $^{13,14}$ or pollen ${ }^{15}, 16$. Allergenic pollen originates from those plants pollinated by air through these represent a smaller percentage in comparison with those pollinated by insects, they release a great number of light pollen grains which are carried by air currents over extensive areas. One of the dominant grass allergens is a plant of the family Poaceae - Phleum pratense (Timothy grass). This plant shows a high stage of taxonomically very diverse cross reactivity ( 80 per cent) not only in the range of its own taxon, but also with other plant species.

In the main, three methods are used in hyposensitization therapy with allergic patients: hypodermic application of aqueous allergen solution, hypodermic application of depot allergen and peroral or sublingual application of drop allergen. Hypodermic application requires frequent medical attendance and it is very unpleasant and painful for some patients, especially children. Peroral (sublingual) administration is carried out at home and it is not painful. As a rule, it results in clinical improvement, however without reflection in the spectrum of specific immunoglobulins of the class IgG. Potentiation of their synthesis makes it possible to monitor the effect of the therapy at a laboratory level and at the same time it makes possible to study induction of the immune response by way of mucous surfaces.

The described experiment is a part of wider problems being studied in the Immunology Institute of the Medical Faculty of the Palacký University in Olomouc. Last year we monitored the effect of peroral allergen application on a murine model, or allergen in connection with selected bacterial strains as the case may be (Klebsiella p., Propionibacterium $a$. and Haemophilus $i$ ). Administration of allergen in combination with bacteria increased the levels of specific $\operatorname{IgG}$ in comparison with the control group, which was given only allergen. A titre of antibodies was evaluated by a standard ELISA test. The following conclusions were drawn:

1. Peroral application of mere allergen and allergen in connection with bacterial adjuvants induces formation of antibodies. 
2. The adjuvant effects of various bacterial strains are different. The highest stimulating effects occurred after Klebsiella p., followed by Propionibacterium a., and an expressively lower effects was obtained after Haemophilus $i$. Pollen also induces specific antibodies, too, but approx. 10 times less, in comparison with Klebsiella p.

3 . These findings are quite original and their development may present a fundamental change in the way therapy is administered by means of peroral hyposensitization. The peroral allergen administration is not time-consuming, it is not painful and there exists a smaller risk of anaphylactic shock in comparison with administration by injection.

The objective of the experiment, supported by an Internal Grant of Palacký University for the year 2000, was to establish the effect of peroral allergen application in connection with bacterial adjuvants ${ }^{17,} 18$ in man.

\section{MATERIAL AND METHODS}

The experimental group consisted of 1 woman and 6 men $(n=7)$, born 1975-1984. Average age $19.9 \pm 3.2$ years. The control group consisted of 4 women and 3 men $(\mathrm{n}=7)$, born 1961-1982. Average age $25.9 \pm 6.4$ years. The patients were hyposensitized by the preparation obtainable commercially from „SEVAC“ (grass pollens). The experimental group was given moreover the bacterial preparation Olimunostim. A standard ELISA test ${ }^{19}$ using antihuman antibody marked by peroxidase was selected for quantification of induced antibodies. The samples were applied in triplets and the experiment was repeated 3 times.

Biological standardization of the preparations obtainable commercially from „SEVAC“ and „Exbio“ and raw pollen extract was carried out by ELISA inhibition. The results are shown in table 3 . The hyposensitization preparations determined for patients were compared with pollen extracts of some pollens from the family of Poaceae in the process of electrophoresis (Fig. 3). As regards the preparations obtainable commercially it was necessary to concentrate the samples in the column Mini Plus from „Millipore“ before spotting them on electrophoresis.

\section{RESULTS}

Table 1 summarizes the average titre values of total specific IgG with experimental and control groups in various treatment stages. The titre values before starting therapy are nearly identical for the experimental and control groups (titre 326, or 291). Graphic expression of table 1 is shown in Fig. 1.

The comparison of percentage growth of antibody titre makes a greater statement has as shown in table 2. Graphic expression of table 2 is given in Fig. 2 as a histogram.

The table 3 shows the results of ELISA inhibition for two delivered preparations (from „SEVAC“ and „Exbio“) and raw pollen extract produced by us and it also compares the effectiveness of the preparations. The effectiveness criterion was preparation concentration (in $\mathrm{PNU}=$ protein nitrogen units) necessary for 50 per cent inhibition of se- rum containing a constant quantity of specific IgE. The most effective preparation was 100 per cent effective, the other preparations had an effectiveness lower than $100 \%$.

Figure 3 shows electrophoretic comparison of hyposensitization preparations and raw pollen extracts of selected plants from the family Poaceae in a 10 per cent SDS-PAGE gel.

Tab 1.: The average rates of specific IgG.

\begin{tabular}{|l|c|c|}
\hline & $\begin{array}{c}\text { Experimental group } \\
\text { (titre) }\end{array}$ & $\begin{array}{c}\text { Control group } \\
\text { (titre) }\end{array}$ \\
\hline Before treatment & 326 & 291 \\
\hline During treatment & 480 & 314 \\
\hline After treatment & 686 & 346 \\
\hline
\end{tabular}

Tab 2.: Percentage of titre increase.

\begin{tabular}{|l|c|c|}
\hline & Experimental group & Control group \\
\hline Before-during & $43 \%$ & $14 \%$ \\
\hline During-after & $64 \%$ & $17 \%$ \\
\hline Before-after & $107 \%$ & $31 \%$ \\
\hline
\end{tabular}

Tab 3.: Results of ELISA inhibition.

\begin{tabular}{|l|c|c|c|}
\hline Specimen & $\mathbf{5 0} \%$ inhibition & List & Efficiency \\
\hline SEVAC & $0,0016 \mathrm{PNU}$ & the best & $100 \%$ \\
\hline Exbio & $3,6 \mathrm{PNU}$ & medium & $0.05 \%$ \\
\hline Raw pollen extract & $10 \mathrm{PNU}$ & the worst & $0.017 \%$ \\
\hline
\end{tabular}

Remark: The best specimen (SEVAC) was associated with $100 \%$ efficiency, others specimens werw reached at $100 \%$.

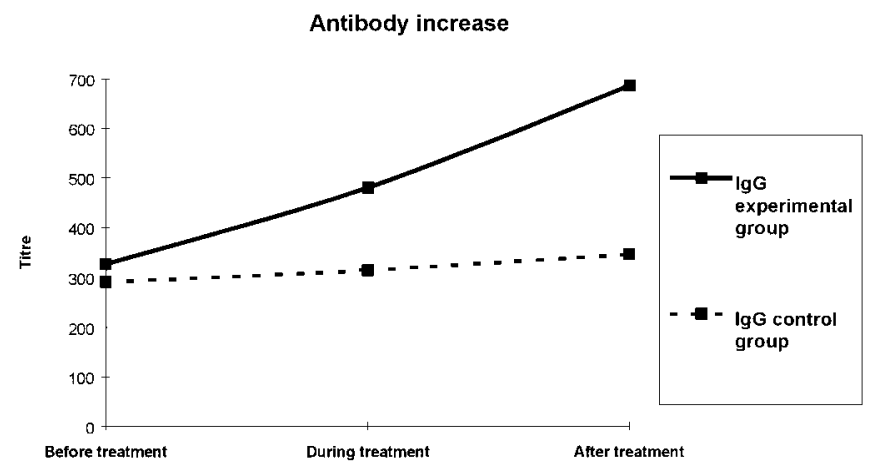

Fig. 1.: Graphic summary - titre increase.

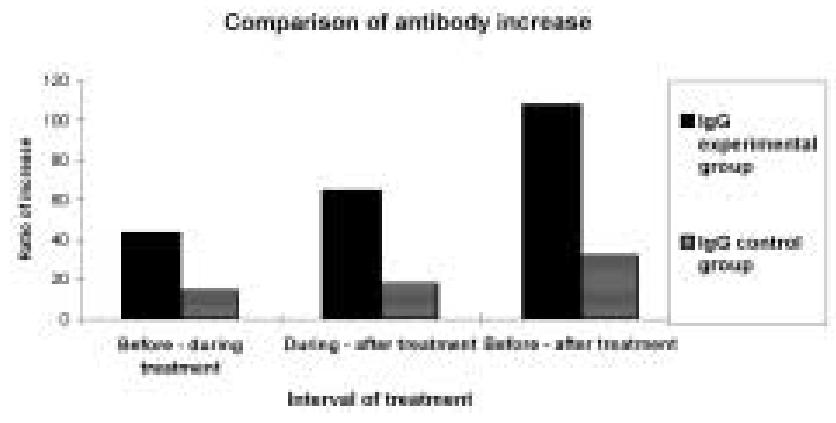

Fig. 2.: Comparison of antibody increase. 


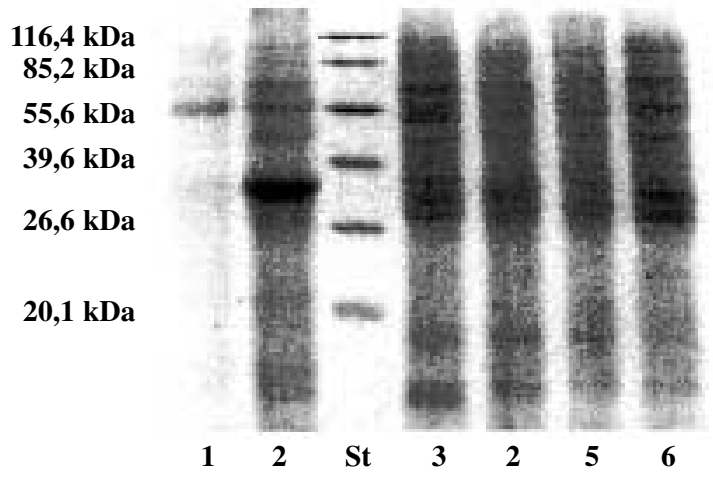

1. SEVAC; 2. Exbio; 3. Standard of MW; 3. Phleum pratense; 4. Lolium perenne; 5. Poa pratensis; 6. Secale cereale.

Fig. 3.: Electrophoretical comparison of hyposenzibilization specimens and raw pollen extracts.

\section{DISCUSSION}

Lysates of some pathogen microorganisms are often and successfully used as immunomodulators $18,23,24$ in clinical practice. The mechanism of the effect of these preparations is not known sufficiently, although, presumably, the common denominator for the most of them are most probably pleiotropic interactions at various levels of nonspecific immune response ${ }^{25}$. The effective components of bacterial immunomodulators are most frequently structural components of cell walls being characteristic of wide microorganism groups, such as Gram-positive and Gram-negative bacteria, or glucan structures being typical for fungal organisms. Generally, they are indicated as pathogen associated molecular patterns ${ }^{26}$.

These structures are ligands for phylogenetically conserved receptors on the surfaces of competent cells designated as ancestral receptors ${ }^{27}$. The bond of relevant ligands on ancestral receptors activates signal paths leading to immunocompetent cell activation.

However, administration of bacterial immunomodulators can have both a protective effect, e.g. during hyposensitization, because it conduces to a concentrated increase in protective (blocking) antibodies, and a negative effect in the form of harmful autoimmune reactions.

Bacterial immunomodulators are most frequently administrated orally. Although a mechanism of signal interference and transduction to immunocompetent cells is not quite clear, presumably, Peyer's patches take part in it. Immunocompetent cells (macrophages and lymphocytes) are informed through their ancestral receptors of the presence of bacterial material ${ }^{17}$.

The recognition activities of nonspecific parts of the immunological system are apparently a key mechanism not only in the immunomodulation process, but they also present a basic mechanism of adjuvant effects of bacterial immunomodulators ${ }^{17,} 18$. Cells of the first contact - epithelial, endothelial and phagocytizing cells as the first line of cell defence - play the main role apparently. The presence of ancestral receptors being capable of distinguishing surface structures of pathogen microorganisms places mucous surfaces in a position of basic parts of nonspecific immunity. This provides better understanding of the fact that mere ad- ministration of usual protein antigen does not challenge on mucous membrane, while the administration of the same antigen when associated with pathogen pattern induces a distinct specific system immune response.

From the results of ELISA tests follows that the presence of bacterial adjuvants enhances the level of total IgG. During it treatment the level of total IgG is increased 43 per cent; the difference before and after treatment is 107 per cent compared to the control group. The group that did not received bacterial adjuvants showed a much smaller growth of $\operatorname{IgG}$ (14 and 31 per cent).

The relationships between structure and immunogenic activity of allergen proteins are not entirely clear. Pollens, fungi, foods and body components of animals or insects are biologically complex materials formed by a mixture of numerous chemical substances and many of them are potential allergens, the remaining substances are ballast substances or they form adjuvant background from the point of view of an allergist.

We established points of 50 per cent inhibition by means of the ELISA test with two hyposensitization preparations from „SEVAC“ and „Exbio“ and with raw pollen extract from Phleum pratense having the same protein concentration (10 000 PNU). This entry can be used as a criterion of biological effectiveness for all preparations. Despite the same protein concentration, the values of 50 per cent inhibition with the preparations of various producers are different. The particular preparations also differ electrophoretically. It is evident from electrophoretic separation that the preparations being obtainable commercially are purified and therefore contain a lower quantity of proteins than raw pollen extract. However, proteins of certain molecular weight (84 and $55,6 \mathrm{kDa}$ ) occur in all observed pollens and they present the main allergens apparently $20,21,22$, i.e. allergens with which at least 50 per cent of allergic patients specific react.

The next stage in the experiment will be the study a larger patient sample and monitor IgG class antigens as well.

\section{ACKNOWLEDGEMENTS}

This work was supported by the grant 1450 1102, the Medical Faculty of the Palacký University 2000 and by CEZ: J14/98:155100002.

\section{REFERENCES}

1. Weiss, S. T. (2000) Parasites and asthma/allergy: What is the relationship?

J. Allergy Clin. Immunol. 105 (2), 205-210.

2. Noon, L. (1911)

Prophylactic inoculation against hay fever.

Lancet $1,1572$.

3. Nelson, H. S. (2000)

The use of standardized extracts in allergen immunotherapy.

J. Allergy Clin. Immunol. 106 (1), 41-45.

4. Nakagava, T. (1991)

The role of IgG subclass antibodies in the clinical response to immunotherapy in allergic disease.

Clin. Exp. Allergy 21, 289-296.

5. Freeman, J. (1911) Further observations on the treatment of hay fever by hypodermic inoculations of pollen vaccine. Lancet 2, 814-817. 
6. Lowenstein, H., Ipsen, H., Lind, P., Mathiesen, F. (1987) The physicochemical and biological characteristics of allergens. In. Lessof, M. H., Lee, T. H., Kemeny, D.M.: Allergy: An international textook. John Wiley and Sons.

7. Kimber, I., Dearman, R. J. (1992)

The mechanisms and evaluation of chemically induced allergy. Toxicol. Lett. 64-65, 79-84.

8. Moharana, A.K., Bhattacharya, S. K., Mediratta, P. K., Sharma K.K. (2000)

Possible role of histamine receptors in the central regulation of immune responses.

Indian J. Physiol. Pharmacol, 44, 153-160.

9. Lie, W. J., Van Der Veen, M. J., Knol, E. F. et al. (2000)

Influence of bronchial allergen challenge on histamine release by human basophils.

Clin Exp Allergy 30, 882-890.

10. Matthiesen, F., Lowenstein, H. (1991)

Group V allergens in grass pollens. I. Purification and characterization of group $\mathrm{V}$ allergen from Phleum pratense pollen, Phl $p \mathrm{~V}$. Clin. Exp. Allergy 21, 297-307.

11. Mohapatra, S. S. (1992) Structural motiefs as basis of crosss-reactivity among pollen allergens. In.: Molecular biology and immunology of allergens.

Allergens Symposium (eds Kraft, D., Sehon, A.), Viena CRC Press. Boca Raton. Ann Arbor. London 1992.

12. Weber, R. W. (1981)

Cross-reactivity among pollens. Ann. Allergy 46, 208-215.

13. Przybilla, B., Ruëff, F. (1999)

Desensitization of allergy to hymenoptera venoms

Wien Med. Wochenschr 14, 421-428.

14. Rancé, F., Abbal, M., Brémont, F., Dutau, G. (1999)

Allergy to hymenoptera venoms in children

Arch Pediatr. 6, 55S-60S.

15. Thomas, W. R. (1991)

Grass under scrutiny.

Clin. Exp. Allergy 21, 255-257.

16. Behrendt, H., Tomczok, J., Sliwa-Tomczok, W., Kasche, A., Ebner von Eschenbach, C., Becker, W..M., Ring, J. (1999)

Timothy grass (Phleum pratense L.) pollen as allergen carriers and initiators of an allergic response.

Int. Arch Allergy Immunol, 118 (2-4), 414-418.
17. Hadden, J. W. (1993)

Immunostimulants. Imm. Today 14, 275-280.

18. Bottex, C., Cristau, B., Corazza, J. L., Mougin, B., Fontanges, R. (1988)

Effect of two bacterial extracts, OM-89 and Broncho-Vaxom, on IL-1 release and metabolic activity of murine macrophage cell-line. Int. J. Immunotherapy 4, 203-212.

19. Harlow, E., Lane, D. (1988)

14 Immunoassays. Antibodies A laboratory manual. Cold Spring Harbor Laboratory, 564-566.

20. Olsen, E., Zhang, L., Hill, R. D., Kisil, F. T., Sehon, A. H., Mohapatra, S. S. (1991)

Identification and characterization of the Poa 9 group of basic allergens of Kentucky blue grass pollen. J. Immunol. 147, 205-211.

21. Fischer, S., Grote, M., Fahlbush, B. (1996) Characterization of Phl p 4, a major timothy grass (Phleum pratense) pollen allergen.

J. Allergy Clin. Immunol. 98, 189-198.

22. Vrtala, S., Susani, M., Sperr, W. R. et al. (1996) Immunologic charakterization of purified recombinant timothy grass pollen (Phleum pratense) allergens ( Phl p 1, Phl p 2, Phl p 5). J. Allergy Clin. Immunol. 97, 781-787.

23. Bessler, W. G., Huber, M., Baier, W. (1997)

Bacterial cell wall components as immunomodulators-II. The bacterial cell wall extract OM-85 BV as unspecific activator, immunogen and adjuvant in mice. Int. J. Immunopharmacol. 19, 551-558.

24. Boháč, S. (2000) Molekulární podstata účinku bakteriálních imunomodulátorů. Alergie 2, 161-167.

25. Hauschildt, S., Kleine, B. (1995)

Bacterial stimulators of macrophage.

International review of cytology 16, 263-322.

26. Medzhitov, R., Janeway, Ch. A. (1997) Innate immunity: impact on the adaptive immune response.

Curr. Opinion in Immunology 9, 4-9.

27. Weigl, E., Raška, M., Petřek, M., Kopeček, P., Hradilová, Š. (1999)

Ancestrální receptory a imunomodulace. Imunologický zpravodaj XIV (2/3), 43-49. 